\title{
ŁÓDŹ RADIOCARBON DATES III
}

\section{ANDRZEJ KANWISZER and PAWEE TRZECIAK}

Archaeological and Ethnographical Museum in Łódź, 91-415 Łódź, pl Wolności 14, Poland

The results presented in this list were obtained from 1986 to 1989 . Equipment, measurement and treatment of samples are as reported previously (Kanwiszer \& Trzeciak 1984: 111). Age calculations are based on a contemporary value equal to $95 \%$ of the activity of NBS oxalic acid standard and on the conventional half-life for ${ }^{14} \mathrm{C}$ of $5568 \pm 30$ years. Results are reported in years before 1950 (years BP). Errors quoted $( \pm 1 \sigma)$ include standard deviations of count rates for the unknown sample, contemporary standard and background. The dates are not corrected for ${ }^{13} \mathrm{C}$ fractionation. Descriptions and comments are based on information supplied by submitters of samples.

\section{ARCHAEOLOGIC SAMPLES}

\section{LOD-220. Nowodworce 1}

$6000 \pm 150$

Wood from archaeologic site in Nowodworce, Białystok prov $\left(53^{\circ} 20^{\prime} \mathrm{N}, 23^{\circ} 25^{\prime} \mathrm{E}\right)$. Material was fragment of stake from $0.6 \mathrm{~m}$ depth. Sample should date site (Cyrek, Grygiel \& Nowak 1982). Coll by K Nowak, Warsaw Univ, Białystok; subm by K Cyrek, Archaeol \& Ethnog Mus, Łódź.

\section{LOD-224. Mały Płock 8c/79}

$740 \pm 140$

Charcoal from archaeologic site in Mały Płock, Łomża prov $\left(53^{\circ} 18^{\prime} \mathrm{N}, 22^{\circ} 02^{\prime} \mathrm{E}\right)$. Sample coll from layer of burned material, from filling of object, depth $1.5 \mathrm{~m}$. Dated to establish correlation of particular settlement phase within site as well as absolute chronology of settlement complex. Date is supplement of Mały Płock series (Kanwiszer \& Trzeciak 1986). Sample coll and subm by E Twarowska, Archaeol Inst, Warsaw Univ, Warsaw.

\section{Brześć Kujawski region series}

Several samples, mainly charcoal, from four archaeologic sites: Brześć Kujawski (52 $36^{\prime} \mathrm{N}$, $\left.18^{\circ} 35^{\prime} \mathrm{E}\right)$, Nowy Młyn $\left(52^{\circ} 37^{\prime} \mathrm{N}, 18^{\circ} 50^{\prime \prime} \mathrm{E}\right)$, Falborz $\left(52^{\circ} 38^{\prime} \mathrm{N}, 18^{\circ} 48^{\prime} \mathrm{E}\right)$ and Guźlin $\left(52^{\circ} 39^{\prime} \mathrm{N}\right.$, $18^{\circ} 52^{\prime} \mathrm{E}$ ), Włocławek prov. Settlement-complex of Lengyel culture in Brześć Kujawski region is one of best dated Neolithic sites. More than 30 dates were obtained from four laboratories: Groningen, Köln, Geochron (Massachusetts), Łódź. These dates help create a chronology of the cultures living in the Brześć Kujawski region in the Early Middle Neolithic (Grygiel 1984). A detailed description of sites and results of previous measurements were published earlier (Kanwiszer \& Trzeciak 1986). All samples coll and subm by R Grygiel, Archaeol \& Ethnog Mus, Łódź.

LOD-225. Nowy Młyn 1

$4950 \pm 160$

Charcoal from lens in hearth, Pit 1, depth $1.0 \mathrm{~m}$. Sample yielded first date of Funnel Beaker culture in this region.

LOD-226. Falborz 4

$6050 \pm 170$

Charcoal, Pit D, depth $0.8 \mathrm{~m}$. 
LOD-228. Falborz 2

$5850 \pm 170$

Charcoal, Pit E, depth $0.8-2.0 \mathrm{~m}$.

LOD-237. Guźlin 6

$5950 \pm 160$

Charcoal, Site 1, Pit 1, depth ca $1 \mathrm{~m}$. Dated to determine absolute chronology of Linear Pottery culture in Brześć Kujawski region.

LOD-291. Nowy Młyn P 11

$5170 \pm 210$

Charcoal from lens in hearth at base of Pit 11, depth ca $1 \mathrm{~m}$.

LOD-292. Nowy Młyn P 13

$5230 \pm 180$

Charcoal from lens in Pit 13, depth $0.6-0.7 \mathrm{~m}$.

LOD-293. Brześć Kujawski S 5/B

$4480 \pm 170$

Charcoal from lens at base of pit, Site 5, Object B, depth ca $0.7 \mathrm{~m}$.

LOD-297. Falborz 2 bis

$5780 \pm 150$

Charcoal from lens in hearth, Pit E, depth $0.8-2.0 \mathrm{~m}$. Dated to confirm or correct date for LOD-228, above.

General Comment: dated material was unutilized part of LOD-228. Date, unsuitable from archaeological viewpoint, is unchanged. The cause of nonconformity with archaeologic expectations probably results from collecting material from too large a depth interval, $0.8-2.0 \mathrm{~m}$.

LOD-298. Brześć Kujawski S 4/755

$3630 \pm 130$

Charcoal from lens in Pit 755 , Site 4, depth $0.8 \mathrm{~m}$.

LOD-315. Brześć Kujawski S 5/H

$4320 \pm 120$

Charcoal from lens in Pit H, Site 5, depth $0.4-0.7 \mathrm{~m}$.

LOD-334. Nowy Młyn P 19

$5030 \pm 170$

Charcoal from lens in hearth of Pit 19, Site 6, depth 0.4-0.6m.

LOD-346. Nowy Młyn P 18

Charcoal from lens in Pit 18, Site 6, depth 0.4-1.0m.

LOD-347. Brześć Kujawski S 3/809

$5220 \pm 140$

Charcoal from lens in Pit 809, Site 3, depth $0.9 \mathrm{~m}$.

LOD-349. Nowy Młyn P 20, 25

$5180 \pm 150$

Charcoal from lenses in Pits 20, 25, Site 6, depth 0.4-1.0m. 


\section{Gniew series}

Six wood samples coll from Gniew, on Vistula River, Gdańsk prov $\left(53^{\circ} 47^{\prime} \mathrm{N}, 18^{\circ} 48^{\prime} \mathrm{E}\right)$. Archaeologic excavations are being conducted in relation to urban renewal and castle reconstruction. Systematic research has revealed traces of Slavic settlement at this locality, eg, a layer from the town's foundation (the decline occurred 13-15th centuries AD). All samples coll from Site 3 and subm by H Paner, Archaeol Mus, Gdańsk.

LOD-230. Gniew 2

Wood fragment from pile of bridge.

LOD-231. Gniew 3

$620 \pm 130$

Wood fragment from pile of bridge; close to gable wall of granary.

LOD-232. Gniew 5

$520 \pm 130$

Wood, peg no. 2, Trench XI A.

LOD-233. Gniew 1

$600 \pm 170$

Wood fragment of board, near granary wall.

LOD-234. Gniew 4

$660 \pm 140$

Wood fragment of timbering board, Trench XI A, near granary wall.

LOD-235. Gniew 6

$630 \pm 140$

Wood fragment of peg, Trench XI B, near granary wall.

\section{Stryczowice series}

Seven samples from Stryczowice, Kielce prov $\left(50^{\circ} 53^{\prime} \mathrm{N}, 21^{\circ} 19^{\prime} \mathrm{E}\right)$. Dated to complement archaeologic research on Neolithic settlement of Funnel Beaker culture (Uzarowicz-Chmielewska 1979). All samples subm by A Uzarowicz-Chmielewska, Natl Archaeol Mus, Warsaw.

LOD-246. Stryczowice 1

$4550 \pm 170$

Charcoal from lens in Pit 3, depth $0.8-1.4 \mathrm{~m}$. Dated to determine chronology of site. Sample coll by A Uzarowicz-Chmielewska and E Krakowiak.

\section{LOD-247. Stryczowice 2}

$4850 \pm 140$

Charcoal scattered throughout large Pit 30, depth $0.8-1.0 \mathrm{~m}$. Dated to determine chronology of large feature of Lengyel culture which covered Funnel Beaker cultural layer. Sample coll by A Uzarowicz-Chmielewska.

LOD-248. Stryczowice 3

$4350 \pm 160$

Charcoal from moat surrounding the settlement, depth $1.3-1.5 \mathrm{~m}$. Dated to determine chronology of moat, the end of its use and the start of its filling by natural elements. Sample coll by A Uzarowicz-Chmielewska. 
LOD-249. Stryczowice 4

Charcoal from peat layer, depth $0.9-1.1 \mathrm{~m}$. Dated to determine chronology of upper moat filling. Sample coll by W Chmielewski.

LOD-250. Stryczowice 5

$4300 \pm 210$

Charcoal scattered through middle and lower part of pit, mainly from darkest streak of pit filling, depth $0.8-1.2 \mathrm{~m}$. Dated to determine chronology of site and to establish whether settlement was single or multi-component. Sample coll by A Uzarowicz-Chmielewska and J Kamińska.

LOD-251. Stryczowice 6

$4700 \pm 160$

Charcoal scattered in bright brown loess with iron precipitation streaks, depth $1.0-1.2 \mathrm{~m}$. Dated to determine chronology of moat and succeeding phases of its filling. Sample coll by W Chmielewski.

LOD-252. Stryczowice 7

$4550 \pm 180$

Charcoal scattered through middle and lower part of pit filling, depth $0.7-1.7 \mathrm{~m}$. Dated to determine age of pit richest in artifacts as well as the age of these artifacts. Sample coll by W Chmielewski.

\section{Kamieńczyk-Błonie series}

Three samples from Kamieńczyk-Błonie, Ostrołęka prov $\left(52^{\circ} 38^{\prime} \mathrm{N}, 21^{\circ} 30^{\prime} \mathrm{E}\right)$. Sites under examination are remains of settlement dating to Roman period. As there were no ceramics, samples were dated to determine chronology of settlement. All samples coll and subm by $G$ Dmochowska, Natl Archaeol Mus, Warsaw. Excavations were made in $10 \mathrm{~m}^{2}$ units (Are), subdivided into Quarters (Qt).

\section{LOD-253. Kamieńczyk-Błonie 1}

$1670 \pm 110$

Charcoal from carbonized beam, depth $0.5 \mathrm{~m}$, Are 11, Qt A, Feature 45.

\section{LOD-254. Kamieńczyk-Błonie 2}

$2300 \pm 140$

Charcoal from carbonized beam from hearth, depth $0.52 \mathrm{~m}$, Are 1, Qt C, Feature 48.

\section{LOD-255. Kamieńczyk-Błonie 3}

$1780 \pm 110$ 64.

Charcoal from outer layer of carbonized beam from hearth, depth $0.4 \mathrm{~m}$, Are 2, Qt A, Feature

\section{LOD-256. Ląkorek 1}

$680 \pm 100$

Wood from site on south bank of Łąkorz Lake, next to stream connecting this lake with Wielkie Partęczyny Lake, Toruń prov $\left(53^{\circ} 27^{\prime} \mathrm{N}, 19^{\circ} 22^{\prime} \mathrm{E}\right)$. Date should help identify stratigraphy and establish chronology of site. Researchers are investigating basal layer of remains of settlement. Sample coll from pile settlement, from post which sank to bottom of Łąkorz Lake, at depth $1.0 \mathrm{~m}$ below water surface. Sample coll and subm by K Grążawski, Reg Mus, Brodnica. 


\section{Grudziądz-Mniszek series}

Two samples from Grudziądz-Mniszek, Torun prov $\left(53^{\circ} 26^{\prime} \mathrm{N}, 18^{\circ} 46^{\prime} \mathrm{E}\right)$. Site is situated on sandy dune. Both results indicate Late Neolithic/Early Bronze Age as well as beginning and end of several cultures at district of Chełm: Únětice, Iwno, Funnel Beaker, Globular Amphora, Pitcomb Ware, Corded Ware. Dates can also prove homogeneous chronology of site. Both samples coll and subm by M Marciniak, Reg Mus, Brodnica.

LOD-257. Grudziądz-Mniszek 3wI/84/c803

$3810 \pm 160$

Charcoal, fragments of large clods from lens at floor of hearth pit. Hearth was in middle of dwelling feature plunged into rockbed, at ca $0.2-0.25 \mathrm{~m}$ depth. Hearth pit was $0.8 \mathrm{~m}$ in diameter, at ca $0.3 \mathrm{~m}$ depth. Clods lying in midst of intensively burned material from $0.8-1.05 \mathrm{~m}$ depth were collected for date.

LOD-258. Grudziądz-Mniszek 3wI/c880

$3770 \pm 150$

Charcoal, scattered fragments of clods from lens in Pit 2. Clods were regularly scattered throughout sandy filling of pit at $0.8-1.3 \mathrm{~m}$ depth.

\section{Kalisz series}

Wood from castle in Kalisz, Kalisz prov $\left(51^{\circ} 48^{\prime} \mathrm{N}, 18^{\circ} 07^{\prime} \mathrm{E}\right)$. Dated to determine beginning of Phase I and intervals of Phases I and II of medieval castle. Samples coll by T Poklewski and J Maik; subm by T Poklewski, Inst Hist Material Culture, Polish Acad Sci, Łódź.

\section{LOD-265. Kalisz III/84}

$600 \pm 90$

Wood, decaying beam and branches from twig layer, Are AB-49/4,9.

LOD-266. Kalisz 437/83

$650 \pm 110$

Wood (batten) from layer of decaying material at base of pit, Are AB-49/4,9.

LOD-267. Kalisz IV/84

$580 \pm 90$

Wood from twig layer in humus underlying foundation of tower castle wall, Are AA-48/10 and $\mathrm{AB}-49 / 6$.

\section{Eykowe series}

Samples from systematic excavation in Łykowe, Sieradz prov $\left(51^{\circ} 12^{\prime} \mathrm{N}, 18^{\circ} 47^{\prime} \mathrm{E}\right)$ (Cyrek, Grygiel \& Nowak 1982; Cyrek 1987, 1990). Series is continuation of archaeologic dates from this site. Detailed description of site with previous Łykowe series were published earlier (Kanwiszer \& Trzeciak 1984, 1986). All samples coll and subm by K Cyrek.

LOD-268. Eykowe 1/85

$4130 \pm 180$

Charcoal from posthole pits, depth $0.8 \mathrm{~m}$, Meter XIV-XVII/ $\mathrm{O}_{16}-\mathrm{O}_{18}$.

LOD-269. Lykowe 2/85

$4250 \pm 160$

Charcoal from cultural pit, depth $0.8 \mathrm{~m}$, Meter XIV/O $\mathrm{O}_{11}$. 
LOD-270. Lykowe 3/85

Charcoal from hearth pit, depth $0.5 \mathrm{~m}$, Meter XXIII and XIV/O ${ }_{11}$.

LOD-271. Lykowe 5/85

$3850 \pm 150$

Wood, fragment of wooden construction beam, depth $1.4 \mathrm{~m}$.

LOD-299. Eykowe 1/86

$4260 \pm 150$

Charcoal from lens in hearth, depth $0.5 \mathrm{~m}$, Meter XX, XXI/ $\mathrm{O}_{20}$.

LOD-300. Lykowe 2/86

$2160 \pm 130$

Charcoal, remnant of wooden construction, depth $0.2-0.4 \mathrm{~m}$, Meter XIV, XV/O ${ }_{20}, \mathrm{O}_{21}$.

LOD-301. Eykowe 6/85

$3850 \pm 160$

Charcoal, hearth traces, depth $1.6 \mathrm{~m}$, near pond, Meter $\mathrm{h}_{1} / \mathrm{B}$.

LOD-302. Eykowe 7/85

$2780 \pm 150$

Organic material from cultural pit, depth $1.3 \mathrm{~m}$, near pond, Meter $h_{1}, i_{1} / B$.

\section{LOD-272. Lednica}

$610 \pm 100$

Sample coll during underwater research near Ostrów Lednicki $\left(52^{\circ} 30^{\prime} \mathrm{N}, 17^{\circ} 23^{\prime} \mathrm{E}\right)$. Initially, two samples were collected for dating - hemp rope and wood from outside bottom layer of boat, but both samples were so small that only a combined sample would yield a reliable result. Since both samples contained comparable amounts of carbon, the obtained result must be interpreted as an average of two dates. Sample coll by M Aleksy, Museum of the First Piasts at Lednica; subm by J Lehman, Natl Mus Poznań.

\section{Osjaków series}

Charcoal from Osjaków, Sieradz prov $\left(51^{\circ} 24^{\prime} \mathrm{N}, 18^{\circ} 45^{\prime} \mathrm{E}\right)$. Samples are from archaeologic excavations of Neolithic settlement on the Warta River (Niesiołowska 1971, 1973). Dated material is mainly related to Pit-comb Ware culture. All samples coll and subm by E Niesiołowska, Archaeol and Ethnog Mus, Łódź.

LOD-273. Osjaków 6/71

Charcoal from layer of sand overlying Hut 3 , depth $0.3 \mathrm{~m}$.

LOD-277. Osjaków 18/69

Charcoal from second layer of fossil soil, depth $1.5 \mathrm{~m}$, Are XV/XVI, Meter b-g.

LOD-278. Osjaków 19/69

Charcoal from hearth, Meter XVIh. 
LOD-279. Osjaków 1/73

$4390 \pm 150$

Charcoal from hearth of dwelling feature, depth $0.7 \mathrm{~m}$, Meter XIVs.

LOD-335. Osjaków 5/70

$4110 \pm 130$

Charcoal from hearth, NS profile, Meter XX B.

LOD-336. Osjaków 4/73

$4320 \pm 130$

Charcoal from hearth, depth $0.5 \mathrm{~m}$, Meter XXI B.

\section{Michałów series}

Charcoal from Michałów, Piotrków Trybunalski prov $\left(51^{\circ} 20^{\prime} \mathrm{N}, 19^{\circ} 29^{\prime} \mathrm{E}\right)$. Samples are from systematic excavations of Mesolithic settlements. All samples coll and subm by E Niesiołowska.

LOD-280. Michałów 10/78

$10,260 \pm 210$

Charcoal from Hearth 5, depth 0.7-0.9m, Meter 12 and 13 B.

LOD-281. Michałów 2/79

$7380 \pm 190$

Charcoal from Hearth 2, depth 0.6-0.7m, Meter 9 A.

LOD-282. Michałów 4,6/80

$7430 \pm 150$

Charcoal from hearth in Hut 1, depth $0.3-0.5 \mathrm{~m}$, Meter $9 / 10 \mathrm{C}$.

LOD-283. Michałów 2/81

$7210 \pm 180$

Charcoal from Hut 2, depth ca $0.4 \mathrm{~m}$, Meter $7 \mathrm{D}$.

\section{Rzucewo series}

Two samples from Osłonino $\left(54^{\circ} 41^{\prime} \mathrm{N}, 18^{\circ} 28^{\prime} \mathrm{E}\right)$ and one from Rzucewo $\left(54^{\circ} 42^{\prime} \mathrm{N}, 18^{\circ} 28^{\prime} \mathrm{E}\right)$, Gdańsk prov. Collected material was related to settlement of Rzucewo culture (Żurek 1954). Dated to establish chronology of Rzucewo culture, particularly settlements lying to west of Vistula River. Samples coll during systematic salvage excavations. All samples coll and subm by D Król, Archaeol Mus, Gdańsk.

LOD-288. Osłonino 1

$4100 \pm 120$

Charcoal from one lens, Pile 2, Excavation 2 - 80, Feature 2 (hut), depth 2.1-2.2m.

LOD-289. Osłonino 2

$4200 \pm 170$

Charcoal from one lens, from burned pile, Excavation $2-80$, Feature 3 (hut), depth $2.25 \mathrm{~m}$.

LOD-290. Rzucewo

$4420 \pm 130$

Charcoal from hearth, Site 1, Borehole 9-25, depth 1.15-1.20m. 


\section{Krzesk-Królowa Niwa series}

Two samples from site in Krzesk-Królowa Niwa, Siedlce prov $\left(52^{\circ} 11^{\prime} \mathrm{N}, 22^{\circ} 25^{\prime} \mathrm{E}\right)$. Dated to establish precise chronology of wooden construction of rampart. Pottery found on site dates to 7th-8th centuries AD. Samples coll and subm by J Kalaga, Archaeol Inst, Warsaw Univ, Warsaw.

\section{LOD-295. Krzesk-Królowa Niwa 1}

Wood, depth $1.45 \mathrm{~m}$.

LOD-296. Krzesk-Królowa Niwa 2

Wood, depth $0.9 \mathrm{~m}$.

\section{LOD-316. Grodzisk 50/84}

Sample coll during systematic excavations in Grodzisk, Siedlce prov $\left(52^{\circ} 25^{\prime} \mathrm{N}, 21^{\circ} 50^{\prime} \mathrm{E}\right)$. Charcoal from pit dwelling with large residues of burned material, depth $1.2 \mathrm{~m}$. Dated to determine age of pit dwelling which is situated within Early Medieval earthwork. Bronze fibula of Middlelathene construction and pottery of Przeworsk culture. Sample coll and subm by W Wróblewski, Archaeol Inst, Warsaw Univ, Warsaw.

\section{Czerchów series}

Two samples from Czerchów, Łódź prov $\left(51^{\circ} 55^{\prime} \mathrm{N}, 19^{\circ} 15^{\prime} \mathrm{E}\right)$. Both samples from Early Medieval earthwork coll and subm by A Chmielowska, Archaeol and Ethnog Mus, Łódź.

LOD-329. Czerchów P 2

$660 \pm 90$

Charcoal, depth $1.1-1.25 \mathrm{~m}$.

\section{LOD-330. Czerchów 5}

$630 \pm 90$

\section{Charcoal.}

\section{Rąty series}

Two samples coll during systematic excavation in Rąty, Gdańsk prov $\left(54^{\circ} 21^{\prime} \mathrm{N}, 18^{\circ} 19^{\prime} \mathrm{E}\right)$. In both cases, charcoal from hearths (layers of burned material with large fragments of carbonized beam) were used. Results seem to determine chronology and cultural attachment of exposed-hearth complex in south part of East Pomeranian cultural cemetery and its probable association with other research sites. Both samples coll and subm by M Fudzinski, Archaeol Mus, Gdańsk.

\section{LOD-331. Rạty 34}

$2320 \pm 90$

Charcoal, depth $0.35-0.40 \mathrm{~m}$, Are XI.

\section{LOD-332. Rạty 41}

$2290 \pm 90$

Charcoal, depth $0.25-0.30 \mathrm{~m}$, Are XXI.

LOD-333. Ruska Skała 1/52

$7120 \pm 210$

Charcoal from Ruska Skała cave in Podlesice, Częstochowa prov $\left(50^{\circ} 50^{\prime} \mathrm{N}, 19^{\circ} 55^{\prime} \mathrm{E}\right)$. Dating 
material coll from cultural layer of cave variety of Świdry culture from early Holocene. Depth ca $1 \mathrm{~m}$. Sample coll by W Chmielewski; subm by K Cyrek.

General Comment: sample was composed of small bits of charcoal that were stored in lignin for 30 years. Most of charcoal was labeled. Despite precision cleaning and pretreatment, there is possibility that not all foreign carbon was removed. Thus, date may be too young.

\section{GEOLOGIC SAMPLES}

\section{WBM series}

This series is continuation of dating of material from geologic sites in Wola Branicka, Łódź prov $\left(51^{\circ} 57^{\prime} \mathrm{N}, 19^{\circ} 27^{\prime} \mathrm{E}\right)$. Detailed description of sites with first WBM series were published earlier (Kanwiszer \& Trzeciak 1986). All samples described below were coll and subm by $\mathrm{H}$ Klatkowa and J Kamiński, Inst Geog, Łódź Univ, Łódź.

\section{LOD-221. WBM 6}

$3600 \pm 140$

Humus from fossil soil layer in dune, depth $2.30-2.55 \mathrm{~m}$. Dated to determine one of duneforming phases.

\section{LOD-222. WBM 5}

$3500 \pm 140$

Peat from organic layer in dune, depth $3.5-3.7 \mathrm{~m}$. Dated to determine beginning of dune formation.

\section{LOD-229. WBM 7}

$7250 \pm 220$

Organic fragments overlying gritty-sand series (river), depth $3.5-3.7 \mathrm{~m}$. Dated to determine end of deposition of coarse river material.

\section{LOD-368. WBM 6,7}

$3090 \pm 100$

Peat from layer, depth $2.05-2.15 \mathrm{~m}$. Dated to determine stratigraphy and paleogeography of Holocene in this region.

\section{LOD-223. Dąbrowa 5/9}

$14,200 \pm 400$

Organic ooze coll by boring from site in Dąbrowa, Piotrków Trybunalski prov $\left(51^{\circ} 36^{\prime} \mathrm{N}\right.$, $19^{\circ} 21^{\prime} \mathrm{E}$ ). Depth $4.8 \mathrm{~m}$. Analysis was carried out to date periglacial dry valley sediments. Sample coll and subm by $\mathrm{H}$ Klatkowa.

\section{Przedbórz region series}

Numerous series of samples from sites on the Pilica River near Przedbórz: Będzyn $\left(51^{\circ} 13^{\prime} \mathrm{N}\right.$, $\left.19^{\circ} 53^{\prime} \mathrm{E}\right)$, Łęg Ręczyński $\left(51^{\circ} 14^{\prime} \mathrm{N}, 19^{\circ} 13^{\prime} \mathrm{E}\right)$, Majkowice $\left(51^{\circ} 10^{\prime} \mathrm{N}, 19^{\circ} 50^{\prime} \mathrm{E}\right)$, Paskrzyn $\left(51^{\circ} 14^{\prime} \mathrm{N}\right.$, $\left.19^{\circ} 52^{\prime} \mathrm{E}\right)$, Skotniki $\left(51^{\circ} 15^{\prime} \mathrm{N}, 19^{\circ} 48^{\prime} \mathrm{E}\right)$ and Taras $\left(51^{\circ} 10^{\prime} \mathrm{N}, 19^{\circ} 52^{\prime} \mathrm{E}\right)$, all Piotrków Trybunalski prov (Marosik 1984). These dates supplement earlier analyses from these sites, which were published earlier (Kanwiszer \& Trzeciak 1986). All samples coll and subm by P Marosik, Archaeol and Ethnog Mus, Łódź.

LOD-227. Będzyn 5

$2950 \pm 150$

Wood from natural outcropping. Sample coll from layer of river sand with wood, depth $1.3 \mathrm{~m}$. 
LOD-243. Majkowice 11

Peat from layer overlying loam silt, depth $2.6 \mathrm{~m}$.

LOD-244. Paskrzyn 3

$12,250 \pm 190$

Sandy silt with plant detritus, depth $1.6-1.7 \mathrm{~m}$.

LOD-261. Taras 1

$6600 \pm 160$

Peat from layer between organic silt and silty sand, depth $1.6-1.7 \mathrm{~m}$.

LOD-262. Paskrzyn 3a

$13,200 \pm 200$

Sandy silt with plant detritus from several layers, depth $1.7-1.8 \mathrm{~m}$.

LOD-263. Paskrzyn 2a

$11,600 \pm 300$

Charcoal, depth $8.5 \mathrm{~m}$.

LOD-264. Majkowice 9

$4530 \pm 160$

Wood with sandy silt underlying peat layer, depth $1.4 \mathrm{~m}$.

LOD-318. Skotniki 1

$10,150 \pm 210$

Peat from basal layer in fossil soil, depth $2.7-2.8 \mathrm{~m}$.

LOD-319. Łęg Ręczyński 4a

$8960 \pm 190$

Peat from basal layer in fossil soil, depth $2.5-2.6 \mathrm{~m}$.

LOD-320. Skotniki 2

$6060 \pm 240$

Peat from basal layer in fossil soil, depth $3.4-3.5 \mathrm{~m}$.

LOD-321. Taras 1a

$10,430 \pm 210$

Peat from basal layer in fossil soil, depth $3.0-3.1 \mathrm{~m}$.

LOD-322. Taras 2

$10,270 \pm 250$

Peat from basal layer in fossil soil, depth $3.3-3.4 \mathrm{~m}$.

LOD-323. Majkowice 11a

$12,860 \pm 250$

Gyttja from basal layer in fossil soil, depth $2.8 \mathrm{~m}$.

LOD-324. Majkowice 12

$4770 \pm 170$

Peat from basal layer in fossil soil, depth $1.45-1.55 \mathrm{~m}$.

LOD-325. Łęg Ręczyński 1

$11,420 \pm 230$

Peat from basal layer in fossil soil, depth $2.4-2.5 \mathrm{~m}$. 
LOD-326. Lęg Ręczyński 2

$10,950 \pm 200$

Peat from basal layer in fossil soil, depth $2.2-2.3 \mathrm{~m}$.

LOD-327. Lęg Ręczyński 4

$7460 \pm 250$

Organic silt from top layer in fossil riverbed, depth $1.4-1.5 \mathrm{~m}$.

LOD-328. Lęg Ręczyński 5 (forest)

$10,270 \pm 220$

Peat from basal layer in fossil riverbed, depth $1.8-1.9 \mathrm{~m}$.

LOD-350. Będzyn 4

$900 \pm 90$

Sandy silt with wood fragments in fossil riverbed, depth 1.1-1.2m.

LOD-351. Będzyn 2

$1310 \pm 100$

Loam silt with plant remains in basal layer of fossil riverbed, depth $1.2-1.3 \mathrm{~m}$.

LOD-352. Lęg Ręczyński 6

$4380 \pm 140$

Peat with many small wood fragments in basal layer of fossil riverbed, depth $1.4-1.5 \mathrm{~m}$.

LOD-353. Majkowice 10

$2720 \pm 110$

Peat with sandy silt in basal layer of fossil riverbed, depth $1.1-1.2 \mathrm{~m}$.

LOD-354. Majkowice 10a

$7520 \pm 160$

Loam silt with many plant remains and wood fragments, in loam silt layer (older mud?) underlying sands and silts (younger mud?), depth $1.6-1.7 \mathrm{~m}$.

\section{Bychlew series}

This is a continuation of previous dates of samples from a site in Bychlew, Łódź prov $\left(51^{\circ} 38^{\prime} \mathrm{N}, 19^{\circ} 21^{\prime} \mathrm{E}\right)$. The site lies close to the upper stretch of the Pabianka River, several meters wide, flowing to the Dobrzynka River in Pabianice. Investigations seem to determine stratigraphy and paleogeography of the Vistulian and Holocene periods in central Poland (Klatkowa 1984). All samples coll and subm by H Klatkowa.

\section{LOD-236. Bychlew XI}

$12,400 \pm 320$

Organic silt from depth $2.55 \mathrm{~m}$.

LOD-259. Bychlew A

$12,300 \pm 250$

Organic silt from depth $1.75 \mathrm{~m}$.

LOD-260. Bychlew B

$4550 \pm 170$

Wood, scattered fragments in organic carbon layer, depth $1.4 \mathrm{~m}$.

LOD-305. Bychlew 85/4.10-4.15

$13,260 \pm 210$

Organic silt from depth $4.10-4.15 \mathrm{~m}$. 
LOD-306. Bychlew 85/4.22-4.30

$13,400 \pm 200$

Organic silt from depth $4.22-4.30 \mathrm{~m}$.

LOD-307. Bychlew 85/4.58-4.65

$14,700 \pm 230$

Organic silt from depth $4.58-4.65 \mathrm{~m}$.

LOD-308. Bychlew 85/4.72-4.75

$14,850 \pm 250$

Organic silt from depth 4.72-4.75.

\section{Lublinek series}

Several samples from Lublinek, Łódź prov $\left(51^{\circ} 44^{\prime} \mathrm{N}, 19^{\circ} 21^{\prime} \mathrm{E}\right)$. Samples collected to investigate geologic structure of the base of the Ner River Valley (Turkowska 1985, 1988, in press). Investigations are being conducted before the construction of a sewage-treatment plant. More information on the site and dating results were published previously (Kanwiszer \& Trzeciak 1986). All samples coll by G Poborska; subm by K Turkowska, Inst Geog, Łódź Univ, Łódź.

LOD-238. Lublinek 1

$12,950 \pm 390$

Organic silt, from branch, depth $4 \mathrm{~m}$. Probably fragment from fossil riverbed.

LOD-239. Lublinek 2

$4900 \pm 170$

Organic ooze from fossil riverbed lens, depth $2.8 \mathrm{~m}$.

LOD-240. Lublinek 3

$4050 \pm 140$

Organic ooze from fossil riverbed, depth $2.2 \mathrm{~m}$.

LOD-241. Lublinek 4

Peat from fossil riverbed, depth $1.2 \mathrm{~m}$.

LOD-242. Lublinek 5

$3150 \pm 150$

Organic ooze from fossil riverbed, depth $0.7 \mathrm{~m}$.

LOD-274. Lublinek 6

$9380 \pm 250$ $3 \mathrm{~m}$.

Riverbed sand with much detritus, from plant detritus lenticel in riverbed sediments, depth ca

LOD-275. Lublinek 9

$9850 \pm 250$

Flood sands with organic detritus in riverbed sediments, depth $4.2 \mathrm{~m}$.

LOD-276. Lublinek 10

$8180 \pm 220$

Organic ooze with detritus from base of fossil riverbed, depth $3.3 \mathrm{~m}$. 
LOD-294. Lublinek 13

Peat and organic ooze from old riverbed, depth $0.8 \mathrm{~m}$.

LOD-342. Lublinek 16

$8350 \pm 160$

Organic ooze from floor of fossil riverbed, depth $1.7 \mathrm{~m}$.

LOD-343. Lublinek 17

$7280 \pm 180$

Organic ooze from roof of fossil riverbed, depth $0.9 \mathrm{~m}$.

LOD-369. Lublinek 20

$2520 \pm 100$

Organic ooze from fossil riverbed, depth $3.4 \mathrm{~m}$.

LOD-370. Lublinek 21

$13,800 \pm 200$

Organic ooze from fossil riverbed, depth $1.75 \mathrm{~m}$.

LOD-371. Lublinek 22

$4000 \pm 130$

Organic ooze from fossil riverbed, depth $1.2 \mathrm{~m}$.

LOD-372. Lublinek 23

$4640 \pm 130$

Organic ooze from fossil riverbed, depth $1.75 \mathrm{~m}$.

LOD-373. Lublinek 24

$8250 \pm 150$

Wood, branch from sandy sediments, depth $1.5 \mathrm{~m}$.

\section{Ślądkowice series}

Several samples from Ślądkowice, Piotrków Trybunalski prov $\left(51^{\circ} 36^{\prime} \mathrm{N}, 19^{\circ} 19^{\prime} \mathrm{E}\right)$, collected from layer of outflow basin in dry valley. Dates may help to determine stratigraphy of Vistulian period. All samples coll and subm by H Klatkowa.

LOD-245. Ślądkowice 40/16

$27,200 \pm 550$

Peat, depth $2.65 \mathrm{~m}$.

LOD-309. Ślądkowice 40/8

$17,800 \pm 400$

Organic silt, depth $1.70 \mathrm{~m}$.

LOD-310. Ślądkowice 40/10

$21,350 \pm 450$

Organic silt, depth $1.90-2.05 \mathrm{~m}$.

LOD-311. Ślądkowice 40/11

$24,350 \pm 450$

Organic silt, depth $2.25 \mathrm{~m}$. 
LOD-312. Ślądkowice 40/14

$26,400 \pm 500$

Organic silt, depth $2.55 \mathrm{~m}$.

LOD-313. Ślądkowice 40/18

$28,600 \pm 550$

Organic silt, depth $2.75 \mathrm{~m}$.

LOD-340. Ślądkowice 2.40-2.55/NS

$25,800 \pm 600$

Organic silt, depth $2.40-2.55 \mathrm{~m}$.

LOD-341. Ślądkowice 2.60-2.70/NS

$29,100 \pm 700$

Peat, depth $2.60-2.70 \mathrm{~m}$.

\section{Michałów (Mokracz) series}

These dates supplement analyses of archaeologic samples from the Michałów site, Piotrków Trybunalski prov $\left(51^{\circ} 20^{\prime} \mathrm{N}, 19^{\circ} 29^{\prime} \mathrm{E}\right)$; other results are published under ARCHAEOLOGIC SAMPLES, this list. These dates help form chronology of Mesolithic site with palaeobotanical information. Both samples coll by P Marosik, subm by E Niesiołowska.

LOD-284. Michałów (Mokracz) 1

$11,270 \pm 210$

Loam gyttja from depth ca $2 \mathrm{~m}$.

LOD-285. Michałów (Mokracz) 2

$8150 \pm 150$

Organic silt from depth ca $1.5 \mathrm{~m}$.

\section{Swędów-Moszczenica series}

Samples coll from Swędów region, Łódź prov $\left(51^{\circ} 51^{\prime} \mathrm{N}, 19^{\circ} 40^{\prime} \mathrm{E}\right)$. Results will help determine 1) the beginning of overgrowth and change in the Moszczenica Riverbed and 2) the beginning of organic sedimentation in the empty riverbed and the age of eolian processes on this section of the Moszczenica River Valley. All samples coll and subm by J Kamiński.

LOD-286. Swędów-Moszczenica 1

$10,370 \pm 250$

Peat from undercut in river, depth $3.25 \mathrm{~m}$.

LOD-287. Swędów-Wieś 2

Peat from old riverbed, depth $0.80-0.90 \mathrm{~m}$.

LOD-303. Moszczenica 1/2.82

$8740 \pm 190$

Peat from undercut in river, depth $2.82 \mathrm{~m}$.

LOD-304. Moszczenica 6/3.45

$10,850 \pm 280$

Organic silt from undercut in river, depth $3.45 \mathrm{~m}$. 
LOD-339. Swędów 1A

$32,800 \pm 900$

Peat, depth $10 \mathrm{~m}$.

LOD-314. Nobela 276/2.10

$3850 \pm 150$

Peat from Nobela village, Sieradz prov $\left(51^{\circ} 41^{\prime} \mathrm{N}, 18^{\prime} 41^{\prime} \mathrm{E}\right)$. Sample coll from base of WartaNiniwka River Valley, depth $2.1 \mathrm{~m}$. Dated to determine stratigraphy of Warta Valley sediments. Sample coll and subm by H Klatkowa.

LOD-317. Bełchatów kop.D

$32,700 \pm 900$

Peat from Bełchatów strip coal mine, Piotrków Trybunalski prov $\left(50^{\circ} 10^{\prime} \mathrm{N}, 19^{\circ} 21^{\prime} \mathrm{E}\right)$. Sample coll from $15 \mathrm{~cm}$ peat layer in sediments filling fossil valley during systematic research of Vistulian sediments in strip mine. Depth ca $6 \mathrm{~m}$. Dated for precise chronology of Vistulian stratigraphy, paleogeography and depositional history of central Poland valleys. Sample coll and subm by B Manikowska, Inst Geog, Łódź Univ, Łódź.

\section{Czołczyn series}

Two samples from site in Czołczyn village, Sieradz prov $\left(51^{\circ} 46^{\prime} \mathrm{N}, 19^{\circ} 10^{\prime} \mathrm{E}\right)$. Dated to analyze stratigraphy of sediments. Both samples coll and subm by W Baliński, Inst Geog, Łódź Univ, Łódź.

\section{LOD-344. Czołczyn 2}

Wood from depth $6.0-6.2 \mathrm{~m}$.

\section{LOD-345. Czołczyn 1}

Peat from depth $1.9-2.5 \mathrm{~m}$.

\section{LOD-357. Troniny 5/3/88}

$10,710 \pm 180$

Sample from archaeologic region in Troniny village, Sieradz prov $\left(51^{\circ} 06^{\prime} \mathrm{N}, 18^{\circ} 45^{\prime} \mathrm{E}\right)$. Dated to study evolution of Warta River Valley. Sample was composed of silt with organic matter, and was coll from fossil riverbed, depth $1.7-1.8 \mathrm{~m}$. Coll by P Marosik; subm by K Cyrek.

\section{LOD-358. Eykowe 1/1/88}

$11,700 \pm 200$

Sample coll from archaeologic region in Łykowe village, Sieradz prov $\left(51^{\circ} 12^{\prime} \mathrm{N}, 18^{\circ} 47^{\prime} \mathrm{E}\right)$. Dated to study evolution of Warta River Valley. Sample was composed of peaty silt and was coll from fossil riverbed, depth $1.8-1.9 \mathrm{~m}$. Sample coll by P Marosik; subm by K Cyrek.

\section{LOD-365. Krzeczów 2/1/88}

$9080 \pm 150$

Sample coll from archaeologic region in Krzeczów village, Sieradz prov $\left(51^{\circ} 09^{\prime} \mathrm{N}, 18^{\circ} 46^{\prime} \mathrm{E}\right)$. Dated to study evolution of Warta River Valley. Sample was composed of peat and was coll from fossil riverbed, depth $3.6-3.7 \mathrm{~m}$. Sample coll by P Marosik; subm by K Cyrek.

\section{Wymokłe series}

Two samples from Wymokłe village, Łódź prov $\left(51^{\circ} 54^{\prime} \mathrm{N}, 19^{\circ} 24^{\prime} \mathrm{E}\right)$. Both samples coll from 
basal layer of outflow basin. Dates will help to determine stratigraphy of Vistulian. Both samples coll and subm by H Klatkowa.

LOD-366. Wymokłe 4/4,5,6

Organic silt, depth $3.58-3.72 \mathrm{~m}$.

LOD-367. Wymokłe 4/37,38

Organic silt, depth 5.92-6.00 m.

\section{Józefów series}

Two samples from Józefów village, Skierniewice prov $\left(51^{\circ} 48^{\prime} \mathrm{N}, 19^{\circ} 52^{\prime} \mathrm{E}\right)$, coll from outside outflow basin by boring. Dates will help create geologic map of Poland. Samples coll and subm by K Nowacki, Warsaw Geol Enterprise, Łódź Dept.

\section{LOD-379. Józefów 1}

Peat, depth $3.96-4.14 \mathrm{~m}$.

\section{LOD-380. Józefów 2}

Peat, depth $8.16-8.34 \mathrm{~m}$.

LOD-381. Jeżów 1

Peat from Jeżów village, Skierniewice prov $\left(51^{\circ} 48^{\prime} \mathrm{N}, 19^{\circ} 57^{\prime} \mathrm{E}\right)$, coll from outflow basin by boring, depth $5.69-5.86 \mathrm{~m}$. Date will help create geologic map of Poland. Sample coll and subm by B Trzmiel, Warsaw Geol Enterprise, Łódź Dept.

\section{REFERENCES}

Cyrek, K 1987 Ort der Spatpalaolitischen Gewinnung und Bearbeitung des Feuersteins. Internatl konf Silexgewnnung Steinwertzeung. Rohstoff Charakterisierung im Karpathenbecken 2: 215-223. Budapest, Sumeg. 1990 Paleolit i mezolit na obszarze woj sieradzkiego. Rocznik Sieradzki 7:28-31.

$\overline{\text { Cyrek}}, \mathrm{K}$, Grygiel, R and Nowak, K 1982 Mezolit ceramiczny w śodkowej i północno-wschodniej Polsce i jego związki z neolitycznymi kulturami niżowymi. Pr Mater Muz Archeol Etnograf Łodzi ser archeol 29: 5-70.

Grygiel, R 1984 The household cluster as a fundamental social unit of the Lengyel culture in the Polish Lowlands. Pr Mater Muz Archeol Etnograf Eodzi ser archeol 31: 43-270.

Kanwiszer, A and Trzeciak, P 1984 Łódź radiocarbon dates I. Radiocarbon 26(1): 111-126. 1986 Łódź radiocarbon dates II. Radiocarbon 28(3): 1102-1109.

Klatkowa, H 1984 Przewodnik knoferencji roboczej nt. Rozwój sieci dolinnej na Wyżynie Łódzkiej w pó́nym plejstocenie i holocenie, Uniw Łódzki, Zakład Badań Czwartorzędu. Inst Geogr Fiz Kszt Środ Łódz: 44-66.

Marosik, P 1984 System starych koryt roztokowych na tle morfologii doliny Pilicy koło Przedborza. Przewodnik konf roboczej nt Rozwoj sieci dolinnej Wyżynie Łódzkiej pónnym plejstocenie holocenie: 30-42.

Niesiołowska, E 1971 Sprawozdanie $\mathrm{z}$ dotychczasowych badań na stanowisku 3 w Osjakowie, pow Wieluń. $\operatorname{Pr}$ Mater Muz Archeol Etnograf Lodzi ser archeol 18: 77-91.

1973 The problem of mesolithic traditions in the neolithic cultures of Poland (selected problems). The Mesolithic in Europe. Warsaw: 441-453.

Turkowska, K 1985 Budowa dna doliny Neru w Lublinku koło Łódzi. Acta Geogr Lodz 50: 125-151. 1988 Rozwój dolin rzecznych na Wyżynie Łódzkiej w późnym czwartorzędzie. Acta Geogr Lodz 57: 1-148.

in press, Main fluvial episodes $\mathrm{i}$ the Ner Valley in the last 22,000 years; a detailed study in Lublinek near Łódź Central Poland. Quaternary Studies in Poland 9.

Uzarowicz-Chmielewska, A 1979 Jamy neolityezne datowane radiowęglem z osady w Stryczowicach woj kieleckie. Wiadomosci Archeol 44: 2.

Zurek, J 1954 Osada w Rzucewie i kultura rzucewska. Fontes Archeol Posnanienes 4: 15-22. 